\title{
Skimmianine as a novel therapeutic agent suppresses proliferation and migration of human esophageal squamous cell carcinoma via blocking the activation of ERK1/2
}

\author{
Yang $\mathrm{LIU}^{1}$, Lin KANG ${ }^{1}$, Shao-Min SHI ${ }^{2}$, Bing-Jie $\mathrm{LI}^{1}$, Yang ZHANG ${ }^{3}$, Xiu-Zhi ZHANG ${ }^{1}$, Xiao-Wan GUO ${ }^{4}$, Gang FU ${ }^{1}$, Guo-Na ZHENG ${ }^{1}$, Han $\mathrm{HAO}^{5, *}$, \\ Huan-Fen $\mathrm{ZHAO}^{1, *}$ \\ ${ }^{1}$ Department of Pathology, Hebei General Hospital, Shijiazhuang, China; ${ }^{2}$ Department of Dermatology, The Third Hospital of Hebei Medical \\ University, Shijiazhuang, China; ${ }^{3}$ Department of Medicinal Chemistry, Hebei Medical University, Shijiazhuang, China; ${ }^{4}$ Department of Radi- \\ ology, Hebei General Hospital, Shijiazhuang, China; ${ }^{5}$ Center of Innovative Drug Research and Evaluation, Hebei Medical University, Shijia- \\ zhuang, China \\ *Correspondence: haohan555@163.com; ZHAO552588@126.com
}

Received November 18, 2021 / Accepted January 17, 2022

\begin{abstract}
Esophageal squamous cell carcinoma (ESCC), one of the main histopathological subtypes of esophageal cancer (EC), is characterized by high morbidity and mortality. Clinical treatment for ESCC lacks specific molecular targets and effective therapeutic drugs. Skimmianine (SK), one of the natural fluroquinolone alkaloids, is widely present in Rutaceae family plants. Here, we mainly used CCK-8 assay, clone formation, flow cytometry analysis, wound-healing assay, Transwell assay, western blot, quantitative real-time PCR (qRT-PCR), molecular docking analysis, tumor xenograft assay, and immunohistochemistry (IHC) staining to investigate the potential anti-tumor effect of SK on ESCC. We demonstrated that SK inhibited the proliferation of TE-1 and Eca109 cells via inducing the G0/G1 phase cell cycle arrest, prevented the migration and invasion of tumor cells via regulating epithelial-mesenchymal transition (EMT) in vitro. In addition, SK obviously suppressed the growth of xenografted Eca109 tumors in nude mice. The anti-tumor mechanism of SK could be blocking the activation of extracellular signal-regulated kinases 1/2 (ERK1/2) in the mitogen-activated protein kinase (MAPK)/ERK signaling pathway. Our basic research suggests that SK can be a potential therapeutic agent for ESCC.
\end{abstract}

Key words: ESCC; proliferation; migration; invasion; ERK1/2

Esophageal cancer (EC) is a malignant tumor with high incidence in clinical practice [1]. The incidence of EC in China accounts for about $46.6 \%$ of the world's EC patients, which has become an important disease threatening people's health, and $90 \%$ of EC cases are diagnosed as esophageal squamous cell carcinoma (ESCC). Despite the advances made in diagnosis and treatment, the 5-year survival rate for ESCC patients ranges from $15 \%$ to $25 \%$ [2-4]. At present, the mechanism of the occurrence and development of ESCC is still unknown, and clinical treatment lacks specific molecular targets and effective therapeutic drugs.

Extracellular signal regulated kinases (ERK), the earliest discovered member of the mitogen-activated protein kinase (MAPK) family, have been widely studied and play an important role in the occurrence and development of cancers [5-7]. The ERK-related intracellular signal transduction pathway, considered to be the classical MAPK pathway, exhibits an important link in a series of kinase cascades that transfer extracellular stimulus signals from the cell membrane to the nucleus. Cytoplasmic ERK activated by phosphorylation can be transferred into the nucleus, then phosphorylate a variety of transcription factors, regulate post-transcriptional gene expression, and ultimately mediate cell growth, differentiation, apoptosis, metastasis, and other processes [8, 9].

Skimmianine ( $\mathrm{SK}, \mathrm{C}_{14} \mathrm{H}_{13} \mathrm{NO}_{4}$ ), one of the natural fluroquinolone alkaloids, is widely present in Rutaceae family plants, including Skimmia, Sweet skimmia, Skimmia arborescens, etc. The main pharmacological features of SK are antiinflammation, anti-pathogenic microorganism, sedation, and analgesia [10-12], while the ephedrine-like effect is weak on animal blood pressure and bronchial asthma [13]. It also has some effects on striated muscle tension and myocardial contraction [14]. But whether SK plays a role in cancer therapy, especially ESCC, is poorly understood. In this study, we found that SK inhibited the proliferation, migration, and invasion of ESCC by modulating the key molecules of the MAPK/ERK pathway, which provided a new target and theoretical basis for the treatment of ESCC. 


\section{Materials and methods}

Reagents. The TE-1 and Eca109 human ESCC lines were purchased from the Shanghai Institutes for Biological Sciences. SK (purity $\geq 99 \%$ ) was purchased from Durst Biotechnology Co., Ltd., China. Human epidermal growth factor (hEGF) was purchased from Proteintech Group, Inc., USA. RPMI-1640, fetal bovine serum (FBS), penicillinstreptomycin (P/S) were obtained from Gibco Life Technologies, USA. CCK8, crystal violet solution, RIPA lysis buffer, DAB chromogenic fluid incubation, Harris hematoxylin, bicinchoninic acid protein kit, DMSO were obtained from Beyotime Biotechnology, China. Propidium iodide (PI) was obtained from Wanleibio, China. Goat serum was purchased from Sangon Biotech Co., Ltd., China.

Cell culture and SK treatment. The TE-1 and Eca109 human ESCC lines were cultured with RPMI-1640 containing $10 \% \mathrm{FBS}$ and $1 \% \mathrm{P} / \mathrm{S}$ in a $37^{\circ} \mathrm{C}$ incubator (Heal force, China) with $5 \% \mathrm{CO}_{2}$. SK dissolved to an initial solution of $100 \mathrm{mM}$ using DMSO, and hEGF dissolved to RPMI-1640. For cell treatment, SK/hEGF were diluted with culture medium to specified concentrations and incubated for a different time.

Cell viability assay. $100 \mu \mathrm{l}$ cell suspension $\left(5 \times 10^{4} / \mathrm{ml}\right)$ was seeded into a 96-well plate in each well, and incubated by different concentrations of SK $(0,25,50,100 \mu \mathrm{M})$ for 24 or $48 \mathrm{~h}$. Then $10 \mu \mathrm{l}$ CCK- 8 was added to each well, and cells continue incubated at $37^{\circ} \mathrm{C}$ for $0.5 \mathrm{~h}$. Cell viability was determined by the absorbance that was measured at $450 \mathrm{~nm}$ with a microplate reader (Fluostar Omega, Germany).

Colony formation assay. Cells were seeded into a 6-well plate at a density of 800 cells per well. After $0,25,50,100 \mu \mathrm{M}$ SK incubation for 14 days, visible colonies were fixed with $4 \%$ formaldehyde at room temperature for $5 \mathrm{~min}$, stained with $5 \mathrm{mg} / \mathrm{ml}$ crystal violet at room temperature for $10 \mathrm{~min}$, counted and normalized to control group.

Wound-healing assay. A linear wound was made using $200 \mu \mathrm{l}$ pipette tips across a culture of confluent cells. Then cells treated $50 \mu \mathrm{M}$ SK or DMSO for 0,24 , or $48 \mathrm{~h}$ were imaged by a microscope imaging system (Olympus, Japan). The wound area was calculated at 0,24 , and $48 \mathrm{~h}$ after scratching using ImageJ 1.8.0.112 software (National Institutes of Health) to assess the cell migration during wound closure. Experiments were repeated at least three times.

Migration and invasion Transwell assay. Transwell assay was performed by using Transwell chambers with $8 \mu \mathrm{m}$ sized pores (Corning, China). The upper chambers with or without
Matrigel (BD) pre-coated were used to test cell invasion and migration assay respectively. Cells cultured to logarithmic growth stage were suspended in an FBS-free medium containing $50 \mu \mathrm{M}$ SK, $20 \mathrm{ng} / \mathrm{ml}$ hEGF, $50 \mu \mathrm{M}$ SK+20 ng/ml hEGF or DMSO at a concentration of $5 \times 10^{5} / \mathrm{ml}$. $200 \mu \mathrm{l}$ cell suspension was added to each upper chamber by micropipette. The bottom chambers were loaded with $500 \mu$ l complete medium. After incubation for $24 \mathrm{~h}$, cells remaining in the upper chambers were carefully removed, stained by crystal violet solution, and observed under a microscope imaging system (Olympus, Japan). Five fields were randomly selected to count the number of cells penetrating the membrane.

Quantitative real-time PCR (qRT-PCR). Total RNA was extracted from tumor cells using RNAiso Plus total RNA extraction reagent (Takara, Japan). cDNA was synthesized using a PrimeScript RT reagent Kit with gDNA Eraser (Takara, Japan). The reaction conditions were as follows: $37^{\circ} \mathrm{C}$ for $15 \mathrm{~min}, 85^{\circ} \mathrm{C}$ for $5 \mathrm{~s}$, and $4^{\circ} \mathrm{C}$ for termination. The real-time PCR was performed on the Bio-Rad CFX 96 Realtime PCR system (BIO-RAD, USA) using SYBR Premix Ex Taq Real-Time PCR Kit (Takara, Japan) and specific primers (Table 1. E-cadherin, N-cadherin, Vimentin, CDK4, Cyclin $\mathrm{D} 1$, and GAPDH). The reaction conditions were one cycle of initial denaturation at $95^{\circ} \mathrm{C}$ for $3 \mathrm{~min}$, followed by 35 cycles of $95^{\circ} \mathrm{C}$ for $30 \mathrm{~s}, 60^{\circ} \mathrm{C}$ for $30 \mathrm{~s}$. The $2^{-\Delta \Delta \mathrm{Cq}}$ method was used to calculate gene expression.

Flow cytometry assay. Cells were seeded in a $25 \mathrm{~cm}^{2}$ tissue culture flask $\left(1 \times 10^{6}\right.$ cells), then treated with $50 \mu \mathrm{M} \mathrm{SK}$ or DMSO for $48 \mathrm{~h}$, fixed with $75 \%$ ethanol overnight, then washed 3 times with PBS. $500 \mu$ l of PI stain solution was added and incubated for $30 \mathrm{~min}$ at $4{ }^{\circ} \mathrm{C}$. Data analysis and acquisition were evaluated using NovoCyte Flow Cytometer (ACEA Biosciences, USA) with 1.3.0 NovoExpress ${ }^{\circledast}$ software (ACEA Biosciences, USA).

Western blot assay. Total proteins extracted from cells using RIPA lysis buffer. The concentrations of proteins were detected using a bicinchoninic acid protein kit. Protein samples were loaded onto $8 \%$ gels and separated by SDS-PAGE. The resolved proteins were electrophoretically transferred to PVDF membranes. The blots were blocked with $5 \%$ non-fat milk in TBS with Tween-20 at room temperature for $1 \mathrm{~h}$ and incubated with primary antibodies, then probed with secondary antibodies, and visualized using the Odyssey Fc System (LI-COR Biosciences, USA). Antibodies specific to $\beta$-actin (cat. no. 66009-1-Ig), CDK4 (cat. no. 11026-1-AP), Cyclin D1 (cat. no. 60186-1-Ig), p-AKT (cat. no. 66444-1-Ig),

Table 1. Primers for $q R T-P C R$.

\begin{tabular}{lll}
\hline Genes & Forward & Reverse \\
\hline E-cadherin & GAGTGCCAACTGGACCATTC & ACCCACCTCTAAGGCCATCT \\
N-cadherin & GTGCATGAAGGACAGCCTCT & TCTCACGGCATACACCATGC \\
Vimentin & GCTGAATGACCGCTTCGCCAACT & AGCTCCCGCATCTCCTCCTCGTA \\
CDK4 & GCCCTCAAGAGTGTGAGAGTC & CACGAACTGTGCTGATGGGA \\
Cyclin D1 & CTGAGGAGCCCCAACAACTT & CAGTCCGGGTCACACTTGAT \\
\hline
\end{tabular}


donkey anti-rabbit (cat. no. SA00001-9), and donkey antimouse (cat. no. SA00001-8) were purchased from ProteinTech Group, Inc., USA (dilution, 1:1000). Antibodies specific to E-cadherin (cat. no. 14472), N-cadherin (cat. no. 13116), Vimentin (cat. no. 5741), p-mTOR (cat. no. 5536T), and PI3K (cat. no. 4249) were purchased from Cell Signaling Technology, Inc., USA (dilution, 1:1000). Antibodies specific to ERK1/2 (cat. no. AF0155) and p-ERK1/2 (cat. no. AF1015) were purchased from Affinity Biosciences, USA (dilution, 1:500). The experiments were repeated at least three times.

Molecular docking analysis. The molecular structure of SK in mol format file (ID: 6502) was downloaded from ChemSpider (http://www.chemspider.com/). The 3D structures of ERK1, ERK2 were found by using RCSB Protein Data Bank online tool (https://www1.rcsb.org/search/advanced). Protein-protein docking was conducted using Discovery Studio software. Bond energy score was identified to judge the degree of intermolecular bonding.

Tumor xenograft assay. Animal experiments were performed in accordance with the Animal Care and Ethical Committee of Hebei General Hospital under the International Association for the Study of Pain guidelines. $12 \mathrm{BALB} / \mathrm{c}-$ nu mice (SPF, Charles River, China) were subcutaneously injected with $1 \times 10^{6}$ Eca109 cells in the left armpit to generate a xenograft mice model. When tumors in the mice reached 50-100 $\mathrm{mm}^{3}$, mice were divided randomly into 2 groups ( $\mathrm{n}=6$ /group): SK (50 mg/kg, dissolved in DMSO) or DMSO injection intraperitoneally every other day. Tumor sizes were measured by calipers and the volumes were calculated using a standard formula: volume $=$ length $\times$ width $^{2} \times \pi / 6$. The tumors of the mice were completely removed after treatment for 28 days.

Immunohistochemistry (IHC) staining. Xenograft tumors excised from the mice were fixed, dehydrated, paraffin embedded, and sliced into sections of $4 \mu \mathrm{m}$ thickness. The sections were deparaffinized in xylene, rehydrated in 100,95 , and $75 \%$ ethanol, and distilled water, put into a microwave for antigen retrieval, then subsequently soaked in $0.3 \% \mathrm{H}_{2} \mathrm{O}_{2}$ to block the activities of endogenous peroxidases and then incubated with $10 \%$ goat serum for $1 \mathrm{~h}$, all at room temperature. Subsequently, the sections were incubated with primary antibody at $4^{\circ} \mathrm{C}$ for $12 \mathrm{~h}$, then incubated with secondary antibody at $37^{\circ} \mathrm{C}$ for $1 \mathrm{~h}$. After DAB chromogenic fluid incubation and Harris hematoxylin staining, the sections were sealed with neutral gum. Images were acquired using an Olympus microscope (Japan). Antibodies used are listed as follows: Ki67 (1:200, Proteintech, cat. no. 27309-1AP), Vimentin (1:200, Cell Signal Technology, cat. no. 5741), p-ERK1/2 (1:100, Affinity, cat. no. AF1015), and goat antirabbit (1:400, Proteintech, cat. no. SA00004-2).

Statistical analysis. Data are presented as the mean \pm SEM for the indicated number of independently conducted experiments and analyzed with Origin 2018 (OriginLab, USA). Statistical significance was evaluated using either two-sample t-test or one-way ANOVA with Tukey correction for multiple groups. Two-way repeated measures ANOVA with Tukey correction was used to analyze xenograft tumor size in vivo. A p-value $<0.05$ was considered to indicate a statistically significant difference.

\section{Results}

SK inhibits the proliferation of ESCC cells in vitro. CCK-8 assay was used to detect the proliferation ability of TE-1 and Eca109 ESCC cells treated by different doses of SK. After treatment with $0,25,50$, and $100 \mu \mathrm{M}$ SK for 24 $\mathrm{h}$ and $48 \mathrm{~h}$, the viability of TE-1 and Eca109 cells showed a dose-dependent decrease (Figure 1A). Specifically, cell viability was reduced to $49.9 \pm 3.77 \%(\mathrm{p}<0.001)$ in TE-1 cells and $54.1 \pm 3.23 \%(\mathrm{p}<0.001)$ in Eca109 cells after treating with $50 \mu \mathrm{M}$ SK for $48 \mathrm{~h}$ compared with $0 \mu \mathrm{M}$ SK groups. Next, the effect of SK on the clone formation was detected by clone formation assay. TE-1 and Eca109 cells treated with 0, 25, 50, and $100 \mu \mathrm{M}$ SK for 14 days also showed a dose-dependent decrease (Figure 1B). Although $25 \mu \mathrm{M}$ SK treatment also had a significant inhibitory effect on the colony-forming activity of ESCC cells, combining with the result of cell viability assay, we finally chose $50 \mu \mathrm{M}$ SK treatment to be mainly used in subsequent experiments. These results suggested that SK could inhibit the proliferation of ESCC cells in a dose-dependent manner.

SK induces G0/G1 phase cell cycle arrest of ESCC cells in vitro. Flow cytometry analysis was performed to determine the role of SK in the cell cycle progression of TE-1 and Eca109 cells. The results showed that the proportion of cells in the G0/G1 phase significantly increased in $50 \mu \mathrm{M}$ SK treatment groups compared with control groups (Figure 2A), which indicated that SK treatment caused G1 phase arrest of ESCC cells. It is well-known that Cyclin D1, CDK4, and the Cyclin D1-CDK4 complex act as the key effectors in the regulation of cell cycle transition from G1 to S phase [15-17]. Therefore, we used western blot and qRT-PCR to detected the protein and mRNA levels of Cyclin D1 and CDK4. Compared with $0 \mu \mathrm{M}$ SK groups, the expressions of CDK4 and Cyclin D1 proteins detected by western blot both in TE-1 and Eca109 cells were significantly decreased after $50 \mu \mathrm{M}$ and $100 \mu \mathrm{M}$ SK treatment (Figure 2B), and the analysis of mRNA levels of Cyclin D1 and CDK4 by qRT-PCR were consistent with the results in western blot (Figure 2C). Taken together, these results indicated that SK-treated TE-1 and Eca109 cells might have led to their arrest at the G0/G1 phase by inhibiting the expression of Cyclin D1 and CDK4 at the transcriptional level.

SK inhibits the migration and invasion of ESCC cells in vitro. Considering that the malignant behavior of ESCC is mainly attributed to its high migration activity, we evaluated the migration and invasion of SK-treated ESCC cells. We found that $50 \mu \mathrm{M}$ SK treatment obviously delayed wound healing of TE-1 and Eca 109 cells at $24 \mathrm{~h}$ and $48 \mathrm{~h}$ compared with the control groups (Figure 3A). Next, we used a Transwell 
A
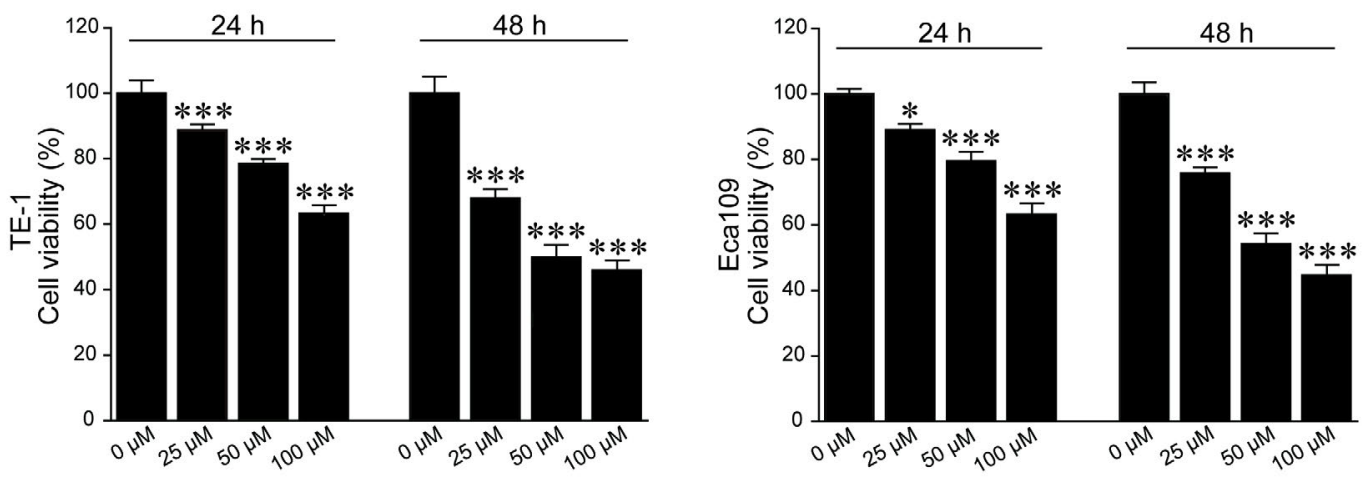

B
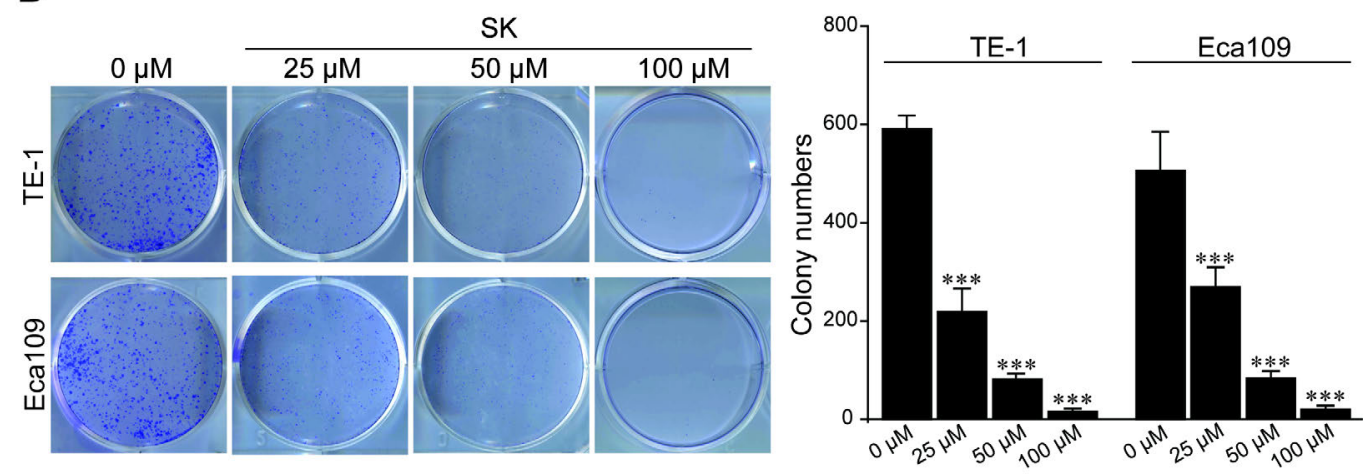

Figure 1. SK inhibited the proliferation of ESCC cells in vitro. A) TE-1 and Ecal09 cells were treated with $0,25,50$, and $100 \mu \mathrm{M}$ SK for $24 / 48 \mathrm{~h}$, and measured by CCK-8 assay to detect the cell viability. Asterisks indicate significant difference from $0 \mu \mathrm{M}$ SK group: ${ }^{\star} \mathrm{p}<0.05$, ${ }^{\star * *} \mathrm{p}<0.001$ (one-way ANOVA with Tukey correction), $n=9$. B) The effects of $0,25,50$, and $100 \mu \mathrm{M}$ SK treatment on the clone formation of TE-1 and Eca109 cells were detected by the clone formation assay. Asterisks indicate significant difference from $0 \mu \mathrm{M}$ SK group: ${ }^{\star * *} \mathrm{p}<0.001$ (two-sample $\mathrm{t}$-test), $\mathrm{n}=5$.

assay to test the effect of SK on the migration and invasion of TE-1 and Eca109 cells. After treatment with 0, 25, 50, and $100 \mu \mathrm{M}$ SK for $24 \mathrm{~h}$ or $48 \mathrm{~h}$, the number of migratory and invasive ESCC cells also showed a dose-dependent decrease to some extent (Supplementary Figure S1). Especially, $50 \mu \mathrm{M}$ SK treatment for $24 \mathrm{~h}$ significantly suppressed the migration and invasion of ESCC cells compared with the control groups (Figure 3B). Furthermore, we detected the mRNA and protein levels of epithelial-mesenchymal transition (EMT) markers including E-cadherin, N-cadherin, and Vimentin. Western blot analysis displayed that the expression of E-cadherin protein was upregulated while the expression of both $\mathrm{N}$-cadherin and Vimentin proteins was downregulated obviously in $50 \mu \mathrm{M}$ and $100 \mu \mathrm{M}$ SK treatment groups, compared with $0 \mu \mathrm{M}$ SK groups (Figure $3 \mathrm{C}$ ). It also showed upregulated E-cadherin mRNA level and downregulated N-cadherin and Vimentin mRNA levels with an SK dose-dependent treatment manner in qRT-PCR analysis (Figure 3D). The above results indicated that $\mathrm{SK}$ regulated the expressions of EMT-related proteins and thereby inhibited the mobility of ESCC cells.
SK impairs ERK1/2-mediated ESCC cell migration and invasion via downregulating the phosphorylation level of ERK1/2 in the MAPK/ERK signaling pathway. The PI3K/ AKT/mTOR and MAPK/ERK signaling pathways play an important role in cell growth, proliferation, invasion, migration, and other physiological and pathological processes [18-19], we hypothesize that SK might affect ESCC cell proliferation and EMT via modulating either or both pathways. To test this possibility, we used western blot to evaluate the expressions of major molecules in the above two pathways. We didn't find a significant difference in the PI3K expression, AKT and mTOR phosphorylation (p-AKT and p-mTOR) levels of TE-1 cells treated with different doses of SK (Supplementary Figure S2). However, the ERK1/2 phosphorylation (p-ERK1/2) level in TE-1 and Eca109 cells were markedly reduced when treated with $50 \mu \mathrm{M}$ and $100 \mu \mathrm{M}$ SK, while the level of ERK1/2 had no change after treating (Figure 4A). Next, we investigated the level of p-ERK1/2 in SK-treated ESCC cells with $20 \mathrm{ng} / \mathrm{ml}$ human epidermal growth factor (hEGF), an agonist of the MAPK/ERK signaling pathway [20, 21]. As shown in Figure $4 \mathrm{~B}, \mathrm{hEGF}$ treatment increased the 
A
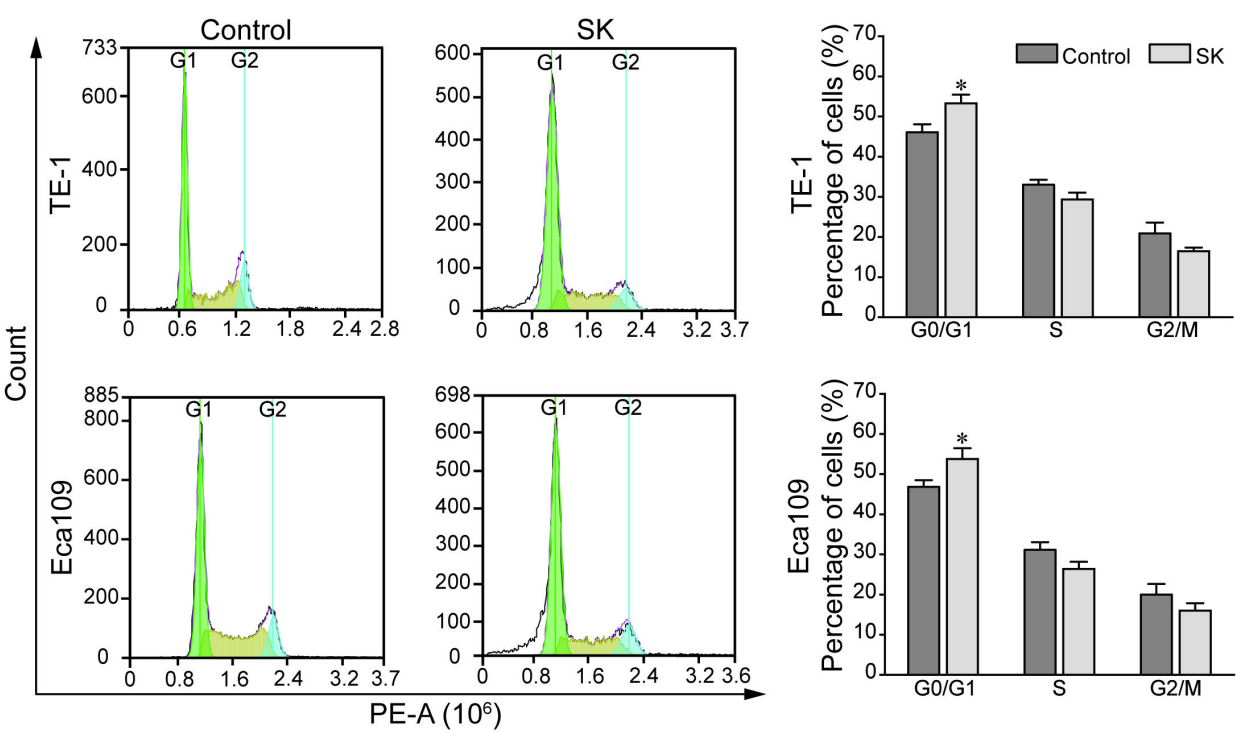

B
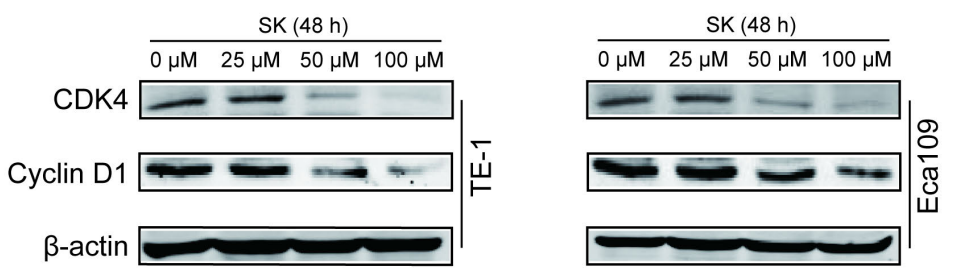

C
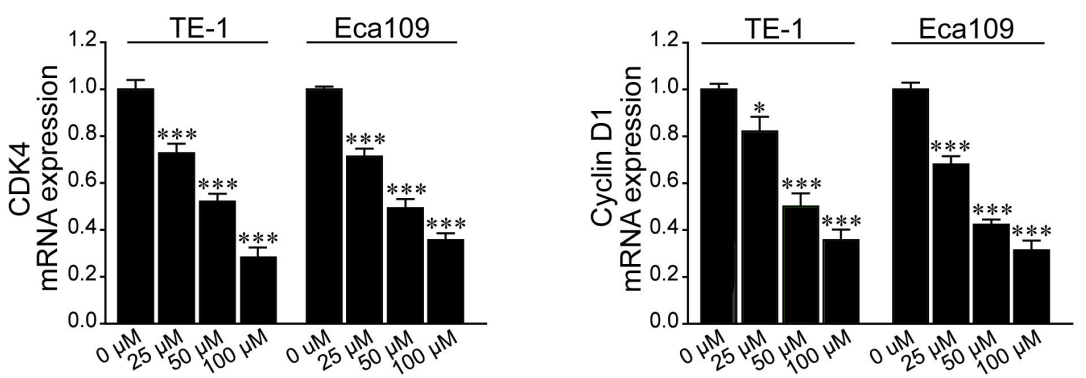

Figure 2. SK treatment resulted in ESCC cells arrest in the G0/G1 phase. A) Flow cytometry analysis was performed to determine the role of $50 \mu \mathrm{M}$ SK treatment for $48 \mathrm{~h}$ in the cell cycle progression of TE-1 and Eca 109 cells. Asterisks indicate significant difference from the control group: ${ }^{\star}$ p $<0.05$ (two sample t-test), $n=6$. B) Western blot and C) $q$ RT-PCR to detect the protein and mRNA levels of Cyclin D1 and CDK4. Asterisks indicate significant difference from $0 \mu \mathrm{M}$ SK group: ${ }^{\star} \mathrm{p}<0.05,{ }^{* * *} \mathrm{p}<0.001$ (one-way ANOVA with Tukey correction), $\mathrm{n}=5$.

protein level of p-ERK1/2 in TE-1 and Eca109 cells without SK applying. However, the enhancing effect on the p-ERK1/2 expression induced by $20 \mathrm{ng} / \mathrm{ml} \mathrm{hEGF}$ was reversed when $50 \mu \mathrm{M}$ SK was co-applied to the tumor cells. The above results suggested that SK inhibited the proliferation, invasion, and migration of ESCC cells at least via downregulating the phosphorylation level of ERK1/2 in the MAPK/ERK pathway.

Previous studies reported hEGF promoted ERK1/2mediated cancer cell migration and invasion [22]. To further verify that SK inhibited ESCC cell migration and invasion through the MAPK/ERK signaling pathway, we used a
Transwell assay to test whether SK could affect hEGF-induced migration and invasion. As shown in Figure 4C, the number of both migratory and invasive cells in TE- 1 and Eca109 cells was increased after $20 \mathrm{ng} / \mathrm{ml} \mathrm{hEGF}$ treatment, dropped after $50 \mu \mathrm{M}$ SK treatment. However, the combination of these two drugs reversed the increasing effect of hEGF to the control level. These results proved that SK suppressed the invasion and migration of ESCC cells by regulating the MAPK/ERK pathway.

SK docks with the phosphorylation sites of ERK1 by molecular docking analysis. To further investigate the 
A
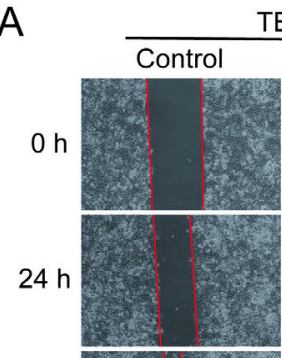

$48 \mathrm{~h}$

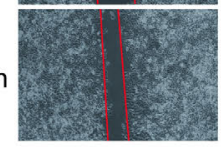

TE-1
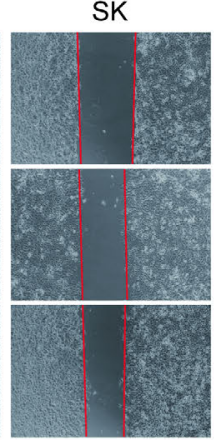
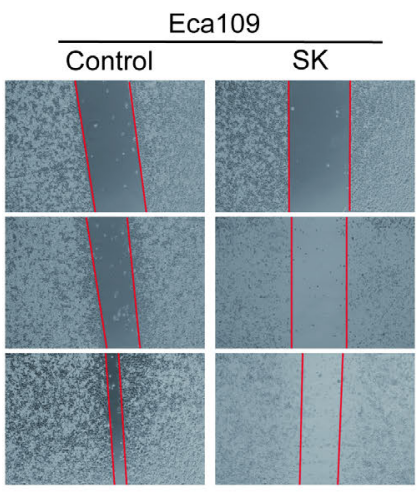

B
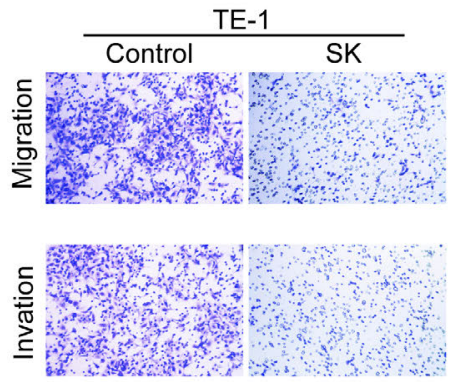

C
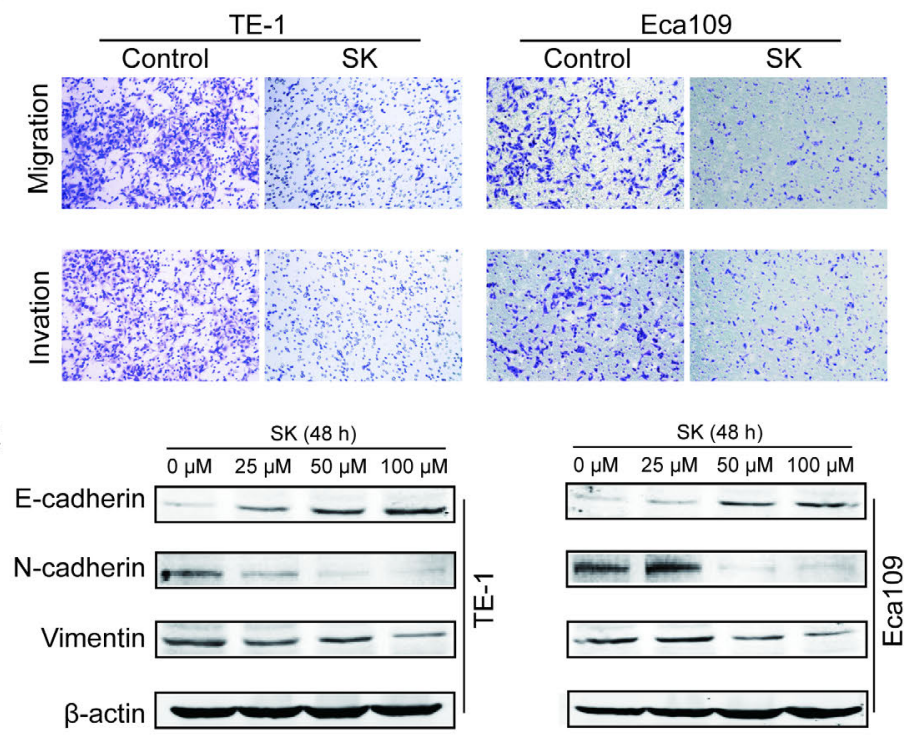

SK $(48 \mathrm{~h})$

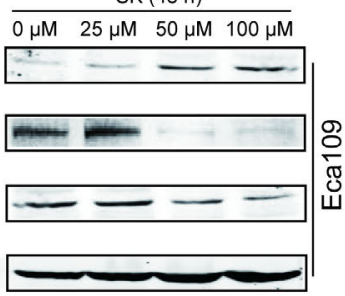

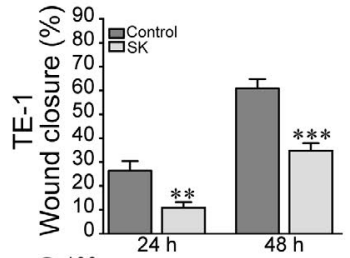
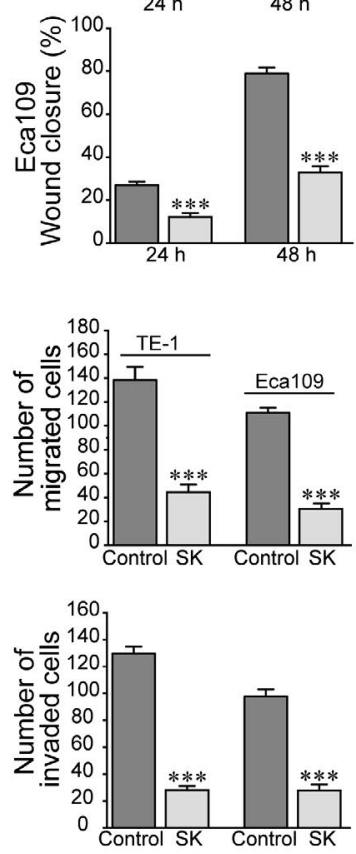

$\mathrm{D}$
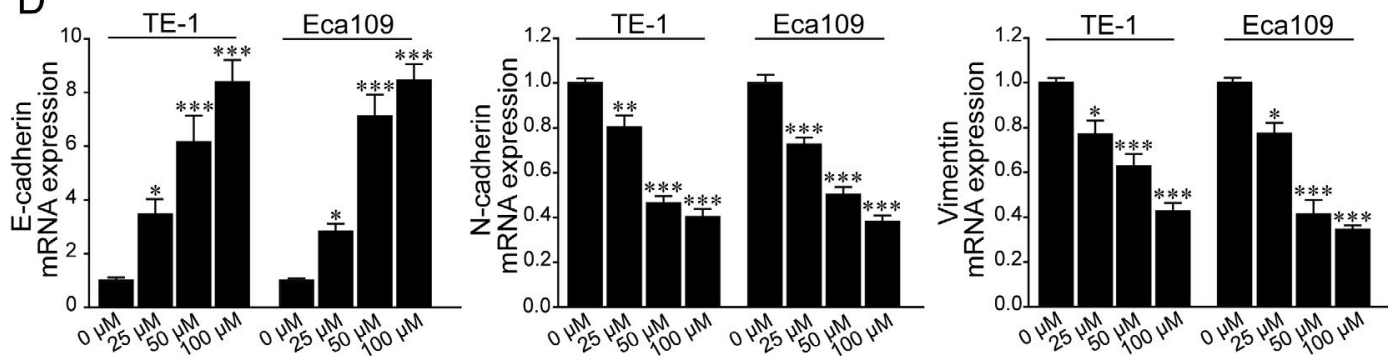

Figure 3. SK inhibited the migration and invasion of ESCC cells in vitro. A) Wound healing assay was used to test the migration of TE-1 and Eca109 cells after $50 \mu \mathrm{M}$ SK treatment for $24 / 48 \mathrm{~h}$. Asterisks indicate significant difference from control group: ${ }^{\star *} \mathrm{p}<0.01,{ }^{\star * *} \mathrm{p}<0.001(\mathrm{two}-\mathrm{sample} \mathrm{t}$-test), $\mathrm{n}=7$. B) Transwell assay was used to test the effect of $50 \mu \mathrm{M}$ SK treatment for $24 \mathrm{~h}$ on the migration and invasion of TE-1 and Eca109 cells. Asterisks indicate significant difference from control group: ${ }^{* *}$ p $<0.001$ (two-sample t-test), $\mathbf{n}=7$. C) Western blot and D) qRT-PCR to detect the protein and mRNA expression of E-cadherin, N-cadherin, and Vimentin. Asterisks indicate significant difference from $0 \mu \mathrm{M}$ SK group: ${ }^{\star} \mathrm{p}<0.05,{ }^{\star *} \mathrm{p}<0.01,{ }^{\star * *} \mathrm{p}<0.001$ (one-way ANOVA with Tukey correction), $\mathrm{n}=5$.

mechanism of SK suppressing ERK1/2 phosphorylation, we next used Discovery Studio software to analyze the structure basis for possible interaction between SK and ERK1/2. The molecular structure of SK was downloaded from ChemSpider, and RCSB Protein Data Bank (PDB) was used to search for the structures of ERK1 (MAPK1-6SLG) and ERK2 (MAPK36GES, Figure 5A). The highest-scored predicted models of interaction between SK and ERK1, SK and ERK2 were 
A

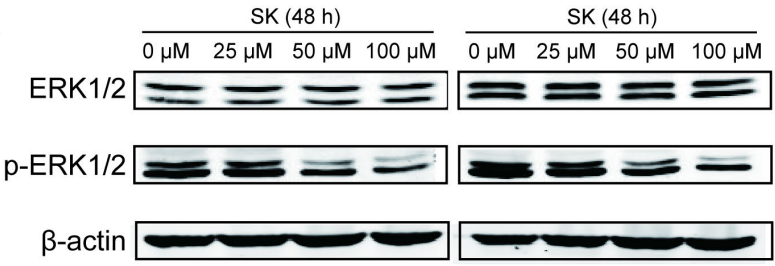

B
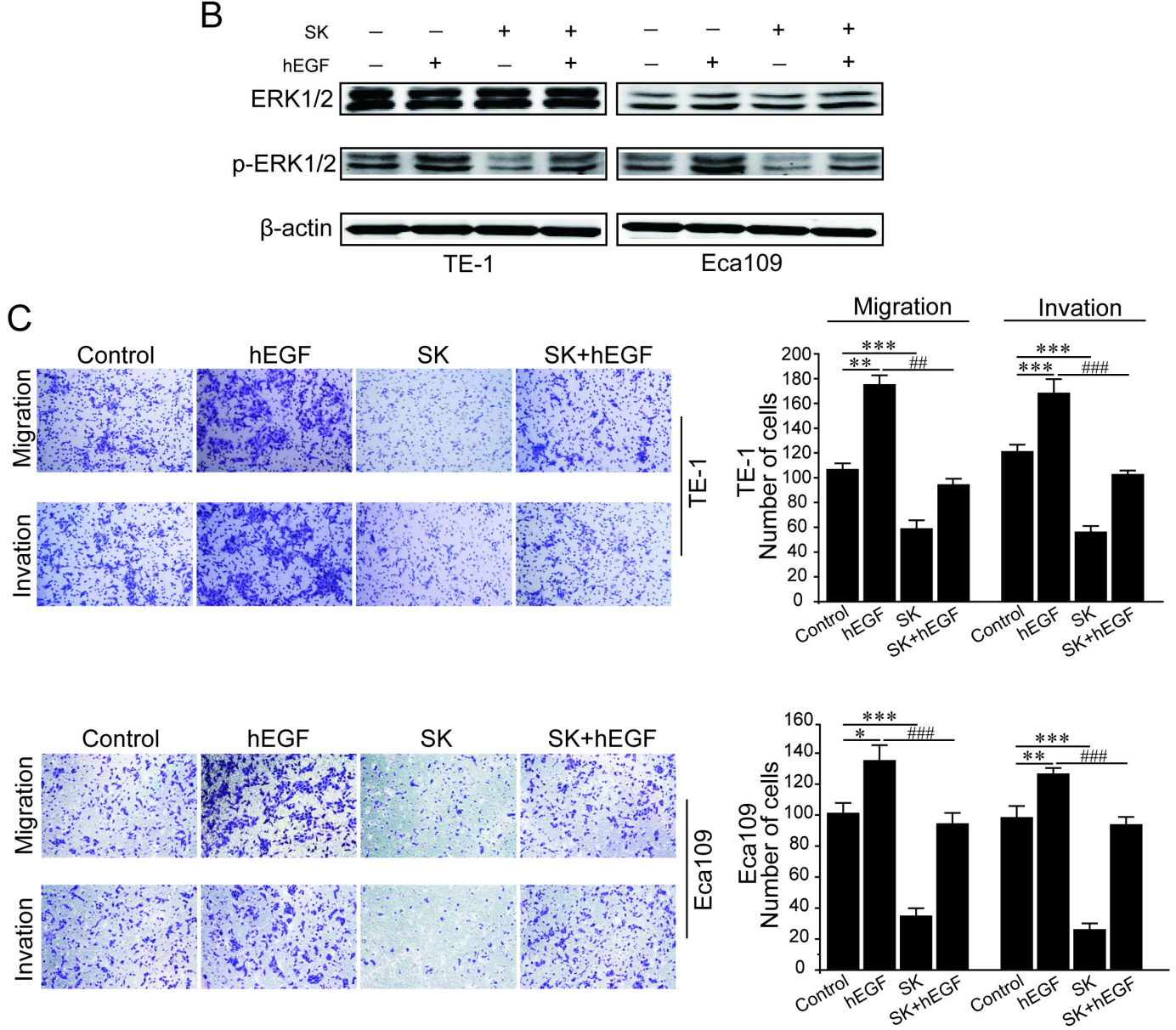

Figure 4. SK impaired ERK1/2-mediated ESCC cell migration and invasion via downregulating the phosphorylation level of ERK1/2. A, B) Western blot detected the protein level of ERK1/2 and p-ERK1/2 of TE-1 and Eca109 cells treated by the different dose of SK for 48 h (A), and $50 \mu M$ SK for 48 $\mathrm{h}$ with or without $20 \mathrm{ng} / \mathrm{ml} \mathrm{hEGF}$ for $3 \mathrm{~h}(B)$. C) Transwell assay was used to test the migration and invasion of TE-1 and Eca109 cells after treating for $24 \mathrm{~h}$ with $50 \mu \mathrm{M} \mathrm{SK}$ in the presence or absence of $20 \mathrm{ng} / \mathrm{ml} \mathrm{hEGF}$. Asterisks and number symbols respectively indicate significant difference from the control group and the $\mathrm{hEGF}$ group: ${ }^{\star} \mathrm{p}<0.05,{ }^{\star *} \mathrm{p}<0.01,{ }^{* * *} \mathrm{p}<0.001 ; \# \mathrm{p}<0.01, \# \# \# \mathrm{p}<0.001$ (one-way ANOVA with Tukey correction), $\mathrm{n}=5$.

discovered by the molecular docking analysis (Figure 5B). ERK is activated by the phosphorylation of both threonine and tyrosine, which then regulates cell growth, differentiation, apoptosis, and metastasis $[23,24]$. Following further analyzing the docking targets between SK and ERK1/2, we found that multiple binding sites were predicted between SK and ERK1/2 (Figure 5C). In particular, SK docked with both threonine and tyrosine of ERK1 (Figure 5C, left), despite having no interaction with the phosphorylation sites of
ERK2 (Figure 5C, right). It suggested that SK might affect the activation of ERK1 via directly acting on its phosphorylation sites, but further studies were needed to prove. This docking analysis revealed the 3D structural basis for possible interactions between SK and ERK1/2.

SK suppresses xenograft tumor growth in vivo. To further explore the effect of SK on xenograft tumor growth, $12 \mathrm{BALB} / \mathrm{c}$-nu mice were injected with $1 \times 10^{6} \mathrm{Eca} 109$ cells in the left armpit to generate a xenograft mice model. When the 
A

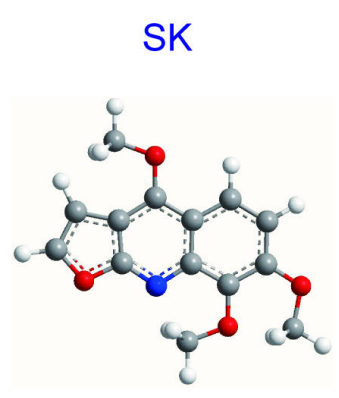

MAPK1-6SLG (ERK1)

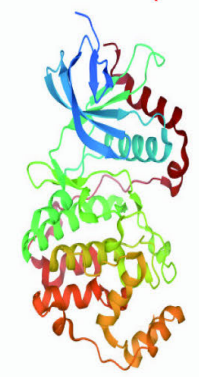

B

SK : MAPK1-6SLG

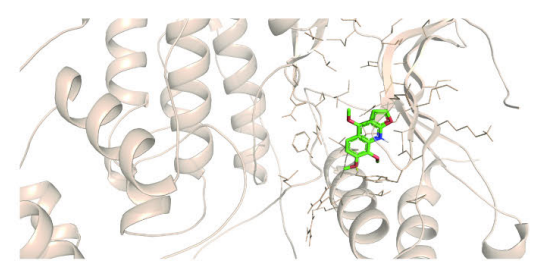

C

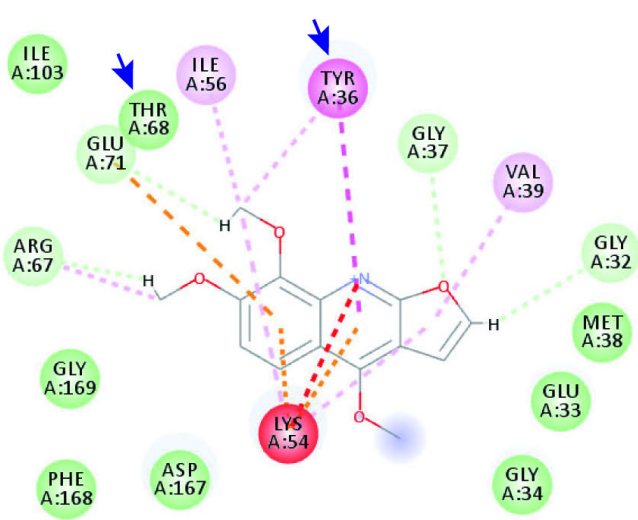

Pi-Sigma

Pi-Pi T-shaped

Alkyl

Pi-Alkyl
MAPK3-6GES (ERK2)

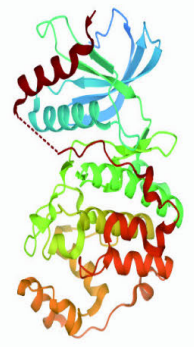

\section{SK : MAPK3-6GES}
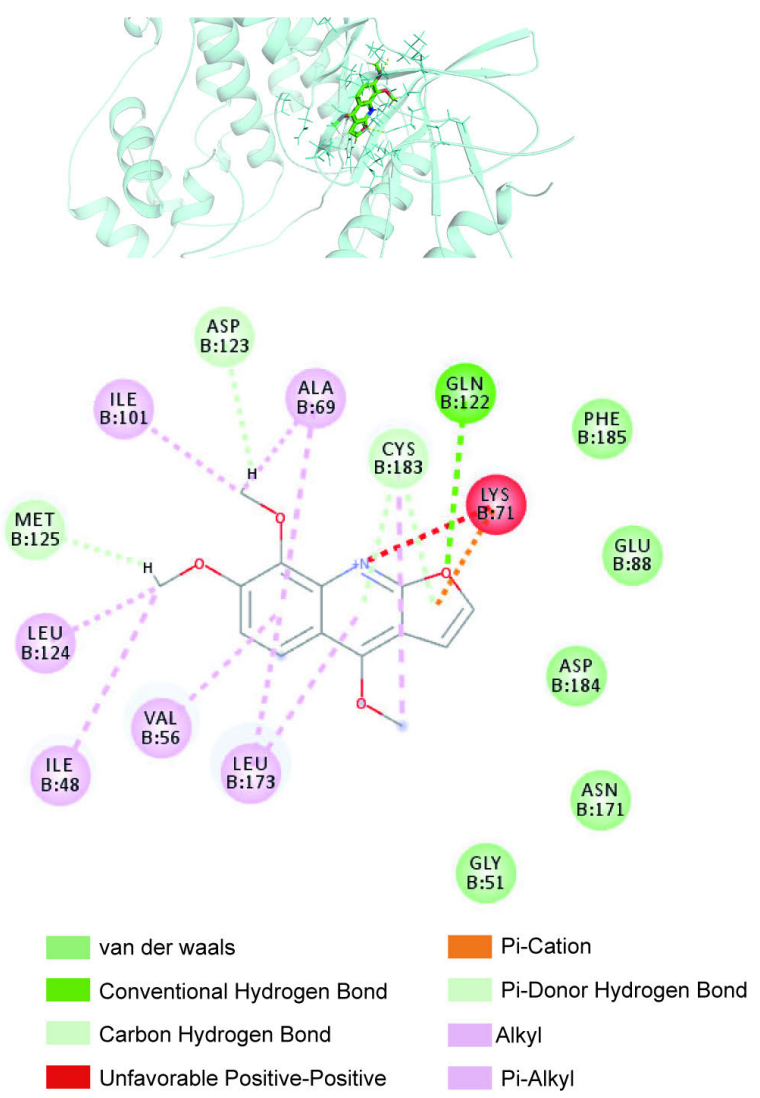

Figure 5. SK docked with the phosphorylation sites of ERK1 by molecular docking analysis. A) The molecular structure of SK, the 3D structures of ERK1 (MAPK1-6SLG) and ERK2 (MAPK3-6GES). B, C) Discovery Studio software predicted the interactions (B) and binding sites (C) between SK and ERK1/2. Arrows indicate threonine and tyrosine of ERK1.

tumors reached $50-100 \mathrm{~mm}^{3}$ after Eca109 cells injection, the mice were divided randomly into 2 groups $(50 \mathrm{mg} / \mathrm{kg}$ SK or DMSO intraperitoneal injection every other day for 28 days). As shown in images of xenograft tumor (Figure 6A), the xenograft tumors treated with SK were obviously smaller than those in the control group. Indeed, SK treatment significantly decreased both the tumor mass and the tumor volume after actual measurement (Figure 6B). We next detected the expression levels of Ki67 (proliferation marker), Vimentin, and p-ERK1/2 in tumor tissues by IHC staining, it showed that all three of them exhibited lower expressions in SK-treated tumor tissues compared with control tissues (Figure 6C). These data suggested that SK is involved in regulating the proliferation and metastasis of ESCC in vivo. 
A
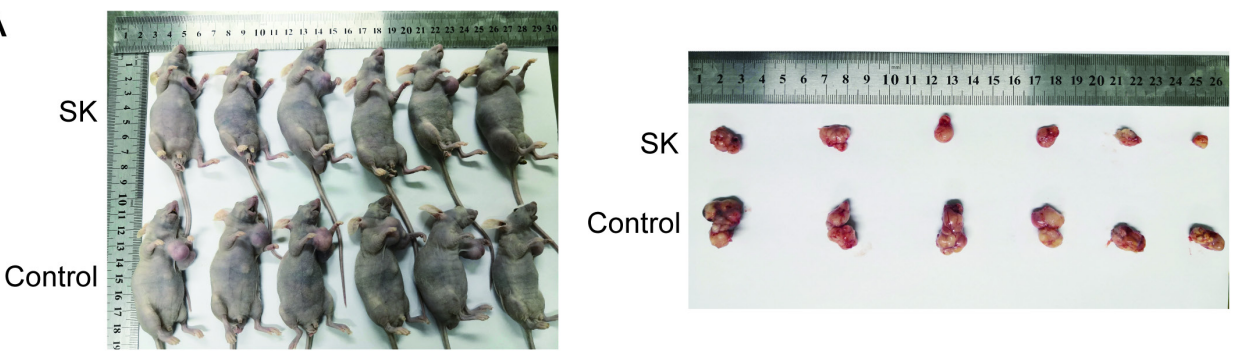

B
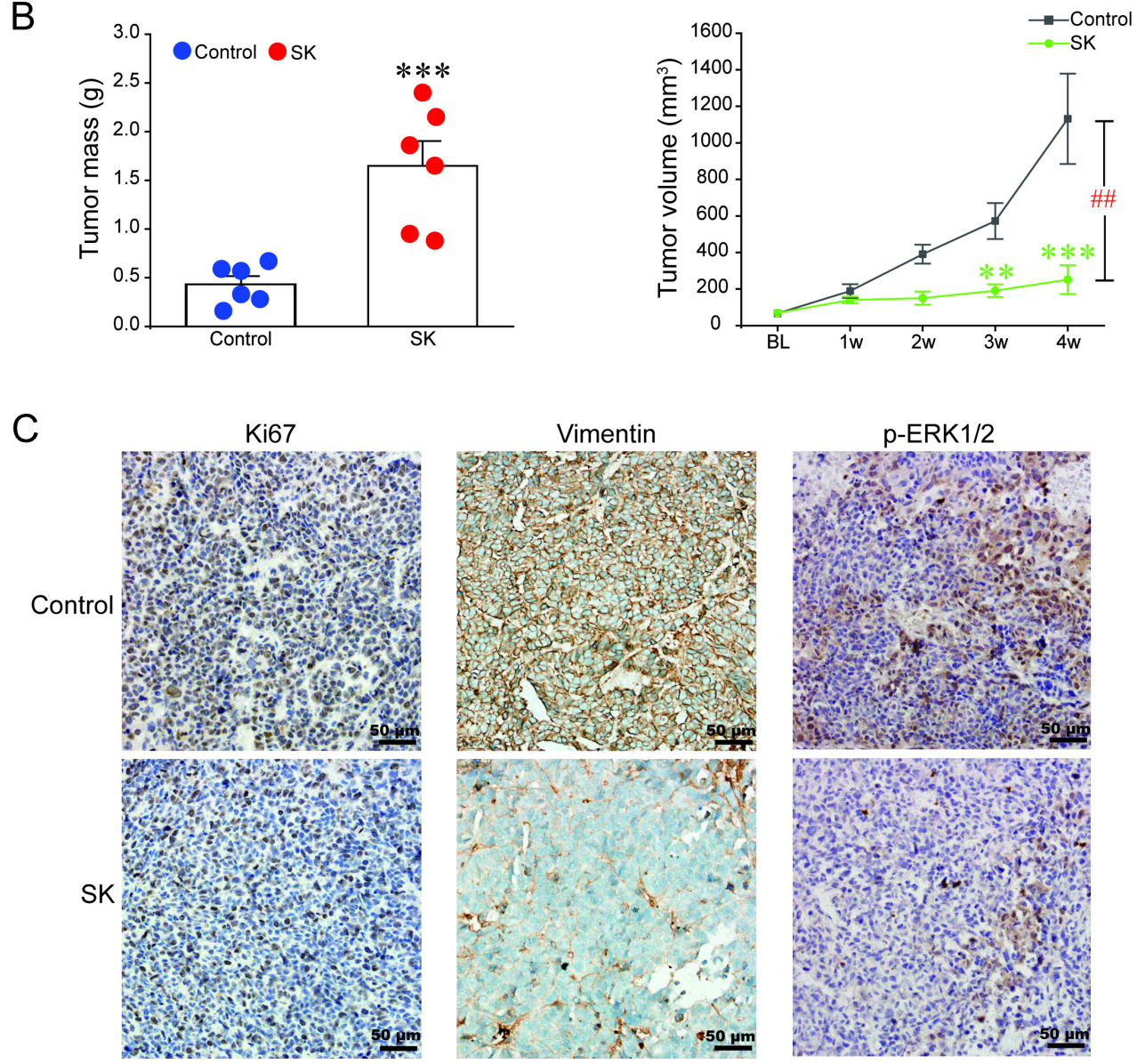

Figure 6. SK significantly suppressed the growth of xenografted Eca 109 tumors in nude mice. A) The images of xenograft tumor after $50 \mathrm{mg} / \mathrm{kg}$ SK (or DMSO) intraperitoneal injection every other day for 4 weeks. B) The effect of SK on the xenografted tumor mass (left). Asterisks indicate significant difference from control group: ${ }^{* *} \mathbf{p}<0.001$ (two-sample t-test). The effect of SK on the xenografted tumor volume (right). Asterisks indicate the difference between groups within the corresponding time point: ${ }^{* *} \mathrm{p}<0.01,{ }^{* * *} \mathrm{p}<0.001$; Number symbols indicate significant difference between SK and the control group data sets: \#\#p<0.01 (two-way repeated ANOVA with Tukey correction), $n=6$. C) The IHC of Ki67, Vimentin, p-ERK1/2 in xenograft tumor tissues. IHC $\times 200$.

\section{Discussion}

EC, one highly malignant gastrointestinal cancer, is the $6^{\text {th }}$ leading cause of cancer-related death worldwide, and ESCC is one of the main histopathological subtypes of EC [3-4]. Although diagnosis and treatment for ESCC have been improved in recent years, the overall survival rate of ESCC patients remains particularly poor due to the characteristics of early invasion and distant metastasis $[25,26]$. The pathogenesis of ESCC involves many factors, elucidating the mechanism of occurrence and progression of ESCC can provide a clinical basis for treatment, and exploration of specific molecular targets could be developed into effective clinical therapeutic agents.

At present, traditional Chinese medicine regarded as one potential anti-tumor treatment has been widely studied, and many effective ingredients of Chinese herbal medicine also have been used in clinical treatment for cancers $[27,28]$. SK, 


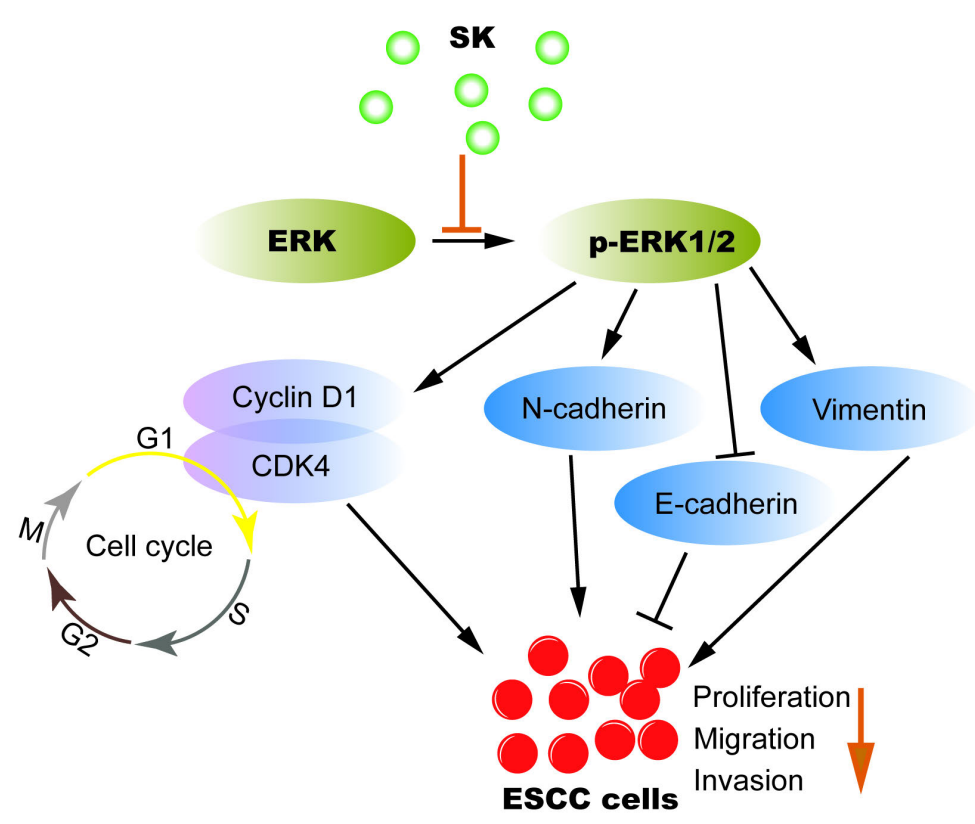

Figure 7. SK inhibited the proliferation of ESCC cells via inducing G0/G1 phase cell cycle arrest, prevented the migration and invasion of ESCC cells through EMT regulation in vitro, and the anti-tumor mechanism of which could be downregulating the phosphorylation level of ERK1/2.

one of the fluroquinolone alkaloids, is widely found in the Rutaceae plants [29]. Through literature review, we found that there are few studies on the pharmacological functions of SK. Ratheesh et al. [11] reported one systematic study on the antiinflammatory effect of SK, which described SK exerted its anti-inflammatory activity in the carrageenan-induced paw edema model, the mechanism of this action is the suppression of pro-inflammatory cytokine production and their upstream events, inhibition of neutrophil infiltration and neutralization of oxidative stress by stimulation of antioxidant enzyme activity. Inflammation is closely related to the development of cancer, and thus anti-inflammatory drugs are often used in the study of tumor therapy. However, the effect of SK on the anti-tumor potential was rarely reported, Zuo et al. [30] revealed SK could significantly inhibit the growth and markedly induce apoptosis of non-small cell lung cancer cells, however, further mechanism of SK acting on non-small cell lung cancer cells still be unclear.

To further research the potential function of SK on the treatment of cancers, we showed that SK significantly inhibited the proliferation of ESCC cell lines with a dose-dependent treatment manner. Although it has been reported that IC50 values for the cytotoxicity of SK against non-small cell lung cancer cells A549, breast cancer cells MCF-7 and human laryngeal epidermoid carcinoma cells HEp-2 were $5.12 \pm 0.81 \mu \mathrm{M}, 50.1 \pm 4.4 \mu \mathrm{g} / \mathrm{ml}$, and $79.4 \pm 5.8 \mu \mathrm{g} / \mathrm{ml} \mathrm{respec}-$ tively [30, 31], in our study $50 \mu \mathrm{M}$ SK treatment for $48 \mathrm{~h}$ inhibited cell viability by $50 \%$. This suggests that SK may have the ability to act on different types of tumors, but it is varied in the effective anti-tumor concentration.
Previous studies had indicated the disorder of cell cycle regulation acted as an important reason for the uncontrolled cell proliferation and carcinogenesis [32, 33]. Different phases of the cell cycle (G1, S, G2, and M) are closely related to key regulatory molecules of the cell cycle. Since the length of cell cycle is mainly determined by the length of the G1 phase, the most important regulatory targets exist in the G1 phase $[34,35]$. Our study showed that ESCC cells with SK treatment could be stagnated in the G0/G1 phase instead of entering the $S$ phase for DNA replication via inhibiting the expression of Cyclin D1 and CDK4.

Uncontrolled proliferation of tumor tissue, abnormal differentiation of tumor cells, and the ability of migration and invasion of tumor cells are regarded as the most basic biological features of malignant cancers. Due to invasion and metastasis primarily threatening the health and life of patients, therefore it is of great significance to study the effect of drugs on tumor migration and invasion [36, 37]. In our study, it indicated that SK inhibited the mobility of ESCC cells via regulating the expressions of EMT-related proteins. Furthermore, SK could reverse hEGF-induced migration and invasion of ESCC cells, which suggested this inhibitory effect of SK could be due to the regulation of the MAPK/ERK pathway.

MAPK/ERK signaling pathway is an evolutionarily conservative signaling pathway that regulates a variety of cellular processes, including cell survival, proliferation, and differentiation $[38,39]$. The core of this pathway presented a kinase cascade consisting of RAF kinase, mitogen-activated protein kinase $(\mathrm{MEK})$, and ERK1/2 kinase. In activating 
many receptor tyrosine kinases (RTK), RAF activated by binding to GTP-binding RAS promoted the phosphorylation of MEK, which then phosphorylates the threonine and tyrosine residues of ERK1/2 to be an activated state. Activated ERK1/2 phosphorylates hundreds of cytoplasmic and nuclear proteins, such as transcription factors and cytoskeletal proteins, which play different roles in a variety of biological processes $[18,19,40]$. In this study, SK treatment directly reduced the expression of $\mathrm{p}$-ERK1/2 and reversed the enhancement effect of hEGF on the level of p-ERK1/2 in ESCC cells, which suggested SK inhibiting the proliferation, migration, and invasion of ESCC cells could be in correlation with the modulation of MAPK/ERK signaling pathway. Next, the molecular docking analysis showed the 3D structural basis for possible interactions between SK and ERK1/2, especially docking with threonine/tyrosine phosphorylation sites of ERK1. This suggested SK might regulate the MAPK/ERK pathway by directly influencing the phosphorylation of ERK1/2. However, there still needs to do more exploration for the deeper mechanism on the effect of SK in ESCC cells. Furthermore, the in vivo efficacy of SK was also confirmed by a xenograft study, in which SK significantly suppressed the growth of xenografted Eca109 tumor in nude mice.

In general, our study demonstrated that SK suppressed proliferation, migration, and invasion of ESCC cells in vitro and the growth of xenografted tumors in vivo. The mechanism of the inhibitory effect of SK on ESCC progression was due to downregulating the level of ERK1/2 phosphorylation in the MAPK/ERK signaling pathway (Figure 7). Our basic research suggests that SK can be a potential therapeutic agent for ESCC. We advocate more studies on the anti-tumor function of SK and further promote the clinical transformation of SK as an effective anti-tumor drug.

Supplementary information is available in the online version of the paper.

Acknowledgments: This research was supported by a fund from the Medical Science Research Project of Hebei Province (20190244).

\section{References}

[1] YANG W, HAN Y, ZHAO X, DUAN L, ZHOU W et al. Advances in prognostic biomarkers for esophageal cancer. Expert Rev Mol Diagn 2019; 19: 109-119. https://doi.org/10.10 80/14737159.2019.1563485

[2] GU H, SHEN Q, MEI D, YANG Y, WEI R et al. Melatonin Inhibits TE-1 Esophageal Cancer Cells Metastasis by Suppressing the NF-кB Signaling Pathway and Decreasing MMP-9. Ann Clin Lab Sci 2020; 50: 65-72.

[3] WANG X, CHENG G, ZHANG T, LEI D, PENG XK et al. CHST15 promotes the proliferation of TE 1 cells via multiple pathways in esophageal cancer. Oncol Rep 2020; 43: 75-86. https://doi.org/10.3892/or.2019.7395
[4] DONG W, LI B, WANG Z, ZHANG Z, WANG J. Clinical significance of microRNA-24 expression in esophageal squamous cell carcinoma. Neoplasma 2015; 62: 250-258. https:// doi.org/10.4149/neo_2015_030

[5] SEGER R, KREBS EG. The MAPK signaling cascade. FASEB J 1995; 9: 726-735.

[6] SAMATAR AA, POULIKAKOS PI. Targeting RAS-ERK signalling in cancer: promises and challenges. Nat Rev Drug Discov 2014; 13: 928-942. https://doi.org/10.1038/nrd4281

[7] CAUNT CJ, SALE MJ, SMITH PD, COOK SJ. MEK1 and MEK2 inhibitors and cancer therapy: the long and winding road. Nat Rev Cancer 2015; 15: 577-592. https://doi. org/10.1038/nrc4000

[8] NEUZILLET C, TIJERAS-RABALLAND A, DE MESTIER L, CROS J, FAIVRE $S$ et al. MEK in cancer and cancer therapy. Pharmacol Ther 2014; 141: 160-171. https://doi. org/10.1016/j.pharmthera.2013.10.001

[9] KIM EK, CHOI EJ. Compromised MAPK signaling in human diseases: an update. Arch Toxicol 2015; 89: 867-882. https://doi.org/10.1007/s00204-015-1472-2

[10] OLILA D, OLWA-ODYEK, OPUDA-ASIBO J. Screening extracts of Zanthoxylum chalybeum and Warburgia ugandensis for activity against measles virus (Swartz and Edmonston strains) in vitro. Afr Health Sci 2002; 2: 2-10.

[11] RATHEESH M, SINDHU G, HELEN A. Anti-inflammatory effect of quinoline alkaloid skimmianine isolated from Ruta graveolens L. Inflamm Res 2013; 62: 367-376. https://doi. org/10.1007/s00011-013-0588-1

[12] CHANG ZQ, WANG SL, HAO CY, LIU F, BIAN CF et al. [Analgesic, antispastic and sedative effects of skimmianine]. Zhongguo Yao Li Xue Bao 1982; 3: 163-165.

[13] GARCÍA-ARGÁEZ AN, RAMÍREZ APAN TO, PARRA DELGADO H, VELÁZQUEZ G, MARTÍNEZ-VÁZQUEZ M. Anti-inflammatory activity of coumarins from Decatropis bicolor on TPA ear mice model. Planta Med 2000; 66: 279-281. https://doi.org/10.1055/s-2000-14894

[14] CHENG JT, CHANG TK, CHEN IS. Skimmianine and related furoquinolines function as antagonists of 5-hydroxytryptamine receptors in animals. J Auton Pharmacol 1994; 14: 365-374. https://doi.org/10.1111/j.1474-8673.1994. tb00617.x

[15] RODERICK HL, COOK SJ. Ca2+ signalling checkpoints in cancer: Remodelling $\mathrm{Ca} 2+$ for cancer cell proliferation and survival. Nat Rev Cancer 2008; 8: 361-375. https://doi. org/10.1038/nrc2374

[16] TASHIRO E, TSUCHIYA A, IMOTO M. Functions of Cyclin D1 as an oncogene and regulation of Cyclin D1 expression. Cancer Sci 2007; 98: 629-635. https://doi.org/10.1111/ j.1349-7006.2007.00449.x

[17] O'LEARY B, FINN RS, TURNER NC. Treating cancer with selective CDK4/6 inhibitors. Nat Rev Clin Oncol 2016; 13: 417-430. https://doi.org/10.1038/nrclinonc.2016.26

[18] MENDOZA MC, ER EE, BLENIS J. The Ras-ERK and PI3KmTOR pathways: Cross-talk and compensation. Trends Biochem Sci 2011; 36: 320-328. https://doi.org/10.1016/j. tibs.2011.03.006 
[19] CHAPPELL WH, STEELMAN LS, LONG JM, KEMPF RC ABRAMS SL et al. Ras/Raf/MEK/ERK and PI3K/PTEN/ Akt/mTOR inhibitors: rationale and importance to inhibiting these pathways in human health. Oncotarget 2011; 2: 135-164. https://doi.org/10.18632/oncotarget.240

[20] LI X, HUANG Y, JIANG J, FRANK SJ. Synergy in ERK activation by cytokine receptors and tyrosine kinase growth factor receptors. Cell Signal 2011; 23: 417-424. https://doi. org/10.1016/j.cellsig.2010.10.016

[21] YANCHUN M, YI W, LU W, YU Q, JIAN Y et al. Triptolide prevents proliferation and migration of Esophageal Squamous Cell Cancer via MAPK/ERK signaling pathway. Eur J Pharmacol 2019; 851: 43-51. https://doi.org/10.1016/j. ejphar.2019.02.030

[22] MA L, LAN F, ZHENG Z, XIE F, WANG L et al. Epidermal growth factor (EGF) and interleukin (IL)-1 $\beta$ synergistically promote ERK1/2-mediated invasive breast ductal cancer cell migration and invasion. Mol Cancer 2012; 11: 79. https://doi. org/10.1186/1476-4598-11-79

[23] CAUNT CJ, MCARDLE CA. ERK phosphorylation and nuclear accumulation: insights from single-cell imaging. Biochem Soc Trans 2012; 40: 224-229. https://doi.org/10.1042/ BST20110662

[24] GALLO S, VITACOLONNA A, BONZANO A, COMOGLIO P, CREPALDI T. ERK: A Key Player in the Pathophysiology of Cardiac Hypertrophy. Int J Mol Sci 2019; 20: 2164. https://doi.org/10.3390/ijms20092164

[25] GERSON JN, SKARIAH S, DENLINGER CS, ASTSATUROV I. Perspectives of HER2-targeting in gastric and esophageal cancer. Expert Opin Investig Drugs 2017; 26: 531-540. https://doi.org/10.1080/13543784.2017.1315406

[26] XU QL, LI H, ZHU YJ, XU G. The treatments and postoperative complications of esophageal cancer: a review. J Cardiothorac Surg 2020; 15: 163. https://doi.org/10.1186/s13019020-01202-2

[27] XIANG Y, GUO Z, ZHU P, CHEN J, HUANG Y. Traditional Chinese medicine as a cancer treatment: Modern perspectives of ancient but advanced science. Cancer Med 2019; 8: 1958-1975. https://doi.org/10.1002/cam4.2108

[28] HE GH, XING DJ, JIN D, LU Y, GUO L et al. Scutellarin improves the radiosensitivity of non-small cell lung cancer cells to iodine-125 seeds via downregulating the AKT/mTOR pathway. Thorac Cancer 2021; 12: 2352-2359. https://doi. org/10.1111/1759-7714.14077
[29] DUKE, JA. Pharmacologically active phytochemicals: skimmianine. In CRC Handbook Medicinal Herbs, CRC Press, Florida 1984, pp. 896. ISBN 9780849312847

[30] ZUO Y, PU J, CHEN G, SHEN W, WANG B. Study on the activity and mechanism of skimmianine against human non-small cell lung cancer. Nat Prod Res 2019; 33: 759-762. https://doi.org/10.1080/14786419.2017.1408096

[31] VARAMINI P, JAVIDNIA K, SOLTANI M, MEHDIPOUR AR, GHADERI A. Cytotoxic activity and cell cycle analysis of quinoline alkaloids isolated from Haplophyllum canaliculatum Boiss. Planta Med 2009; 75: 1509-1516. https://doi. org/10.1055/s-0029-1185807

[32] MARX J. How cells cycle toward cancer. Science 1994; 263 : 319-321. https://doi.org/10.1126/science.8278804

[33] GOEL S, DECRISTO MJ, MCALLISTER SS, ZHAO JJ. CDK4/6 Inhibition in Cancer: Beyond Cell Cycle Arrest. Trends Cell Biol 2018; 28: 911-925. https://doi.org/10.1016/j. tcb.2018.07.002

[34] HWANG Y, HIDALGO D, SOCOLOVSKY M. The shifting shape and functional specializations of the cell cycle during lineage development. Wiley Interdiscip Rev Syst Biol Med 2020; 11: e1504. https://doi.org/10.1002/wsbm.1501

[35] SALOMONI P, CALEGARI F. Cell cycle control of mammalian neural stem cells: putting a speed limit on G1. Trends Cell Biol 2010; 20: 233-243. https://doi.org/10.1016/j. tcb.2010.01.006

[36] LIN Y, XU J, LAN H. Tumor-associated macrophages in tumor metastasis: biological roles and clinical therapeutic applications. J Hematol Oncol 2019; 12: 76. https://doi. org/10.1186/s13045-019-0760-3

[37] DUFF D, LONG A. Roles for RACK1 in cancer cell migration and invasion. Cell Signal 2017; 35: 250-255. https://doi. org/10.1016/j.cellsig.2017.03.005

[38] ZHAO C, WU H, CHEN P, YI B, MA Y et al. MAT2A/2B promote porcine intramuscular preadipocyte proliferation through ERK signaling pathway. Anim Sci J 2019; 90: 1278 1286. https://doi.org/10.1111/asj.13264

[39] DESCHÊNES-SIMARD X, KOTTAKIS F, MELOCHE S, FERBEYRE G. ERKs in cancer: friends or foes? Cancer Res 2014; 74: 412-419. https://doi.org/10.1158/0008-5472.CAN$13-2381$

[40] SANTOS E, CRESPO P. The RAS-ERK pathway: A route for couples. Sci Signal 2018; 11: eaav0917. https://doi. org/10.1126/scisignal.aav0917 
https://doi.org/10.4149/neo_2022_211118N1640

\section{Skimmianine as a novel therapeutic agent suppresses proliferation and migration of human esophageal squamous cell carcinoma via blocking the activation of ERK1/2}

Yang $\mathrm{LIU}^{1}$, Lin $\mathrm{KANG}^{1}$, Shao-Min $\mathrm{SHI}^{2}$, Bing-Jie $\mathrm{LI}^{1}$, Yang ZHANG ${ }^{3}$, Xiu-Zhi ZHANG ${ }^{1}$, Xiao-Wan GUO ${ }^{4}$, Gang FU ${ }^{1}$, Guo-Na ZHENG , Han $\mathrm{HAO}^{5, *}$, Huan-Fen $\mathrm{ZHAO}^{1, *}$

Supplementary Information
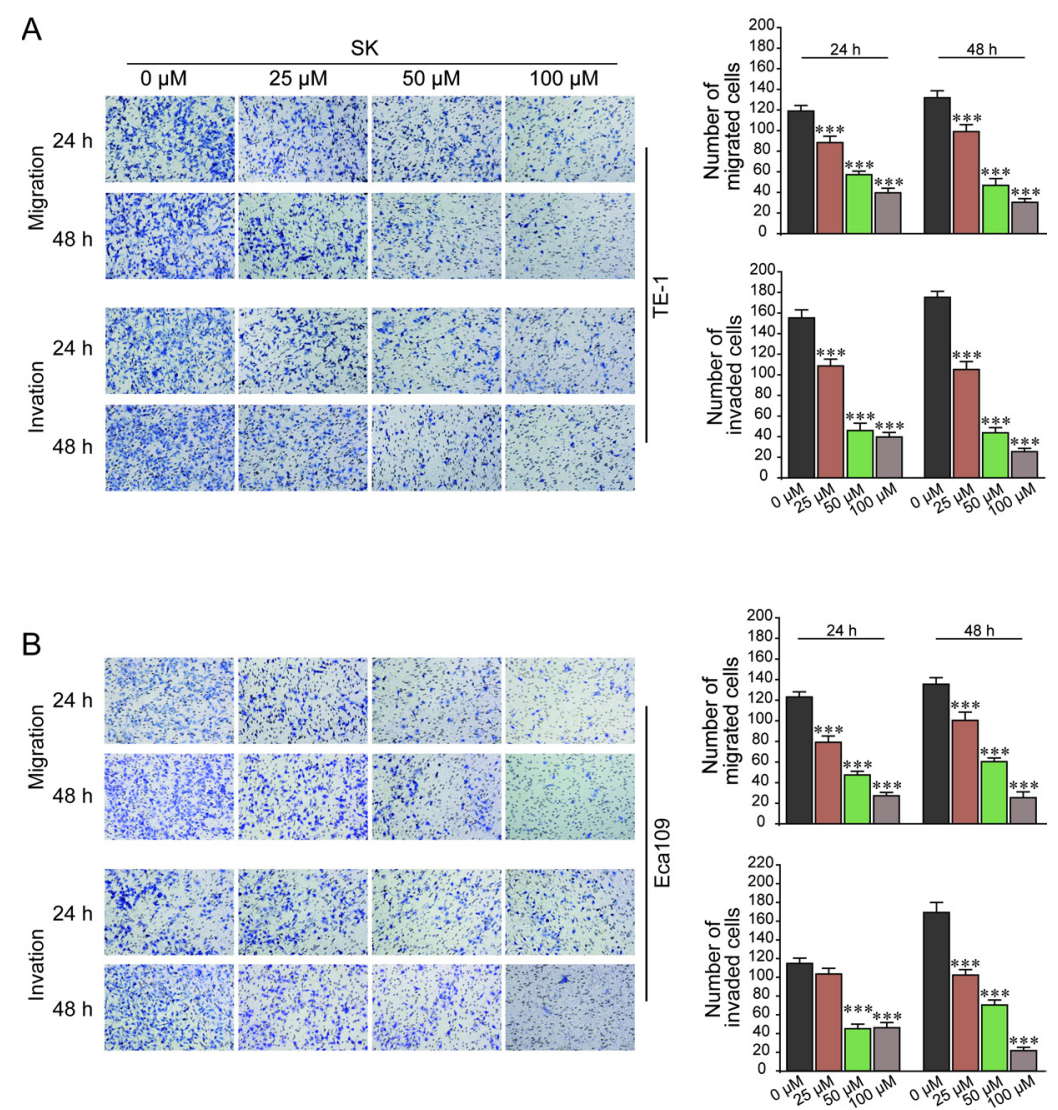

Supplementary Figure S1. To observe the migration and invasion of ESCC cells treated with different concentrations of SK. Transwell assay was used to evaluate the effect of $0,25,50$ and $100 \mu \mathrm{M}$ SK treatment for 24/48 h on the migration and invasion of TE-1 (A) and Eca109 (B) cells. Asterisks indicate significant difference from $0 \mu \mathrm{M}$ SK group: ${ }^{* *} \mathrm{p}<0.001$ (one-way ANOVA with Tukey correction), $\mathrm{n}=5$.

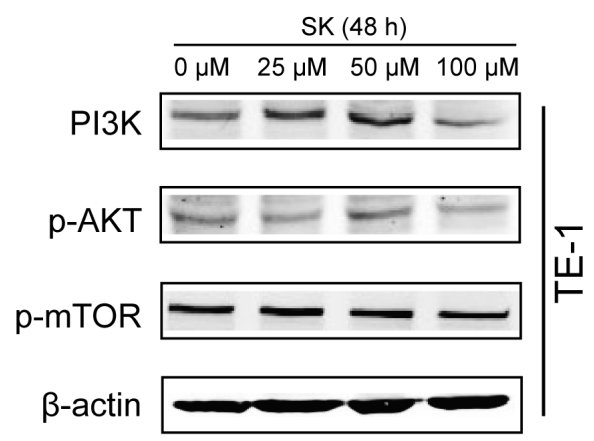

Supplementary Figure S2. SK had no obvious effect on PI3K/AKT/mTOR signaling pathway. Western blot was used to detect the protein level of PI3K, p-AKT and p-mTOR. 